\title{
A patient with bulimia nervosa and profound folate deficiency
}

\author{
D.J. Eedy, J.G. Curran and W.J. Andrews \\ Whiteabbey Hospital, Newtownabbey, Co. Antrim BT37 9RH, Northern Ireland.
}

\begin{abstract}
Summary: A case is reported of a young woman with bulimia nervosa who presented with profound folate deficiency. This association has not been reported before despite the increased theoretical possibility. Initially she has responded well to folic acid therapy and social support.
\end{abstract}

\section{Introduction}

Bulimia nervosa, a syndrome characterized by powerful urges to overeat despite a morbid fear of fatness, is predominantly a condition of adolescent and young females, where profound weight loss, amenorrhoea and abnormal sexual adjustment are less frequently found than anorexia nervosa (Russell, 1979; Hertzog \& Copeland, 1985). While it is recognized that there may be considerable overlap in the eating habits encountered in these inter-related disorders, anorexia nervosa patients tend to pursue weight loss more by dietary restriction, while bulimia nervosa is characterized by secretive binge-eating following by selfinduced vomiting, fasting or the abuse of laxatives or diuretics (Hertzog \& Copeland, 1985).

Mild or moderate anaemia has been noted both in bulimia and anorexia nervosa but serum $\mathbf{B}_{12}$ and folate together with red and white cell morphology are usually normal (Mant \& Farragher, 1972; Harris, 1983; Hertzog \& Copeland, 1985).

\section{Case history}

The patient was a 17 year old factory worker. She was referred because of a 4-month history of persistent and unexplained vomiting. Her family doctor revealed that the girl was illegitimate and her real father had deserted the family shortly after her birth. Her mother worked during the day and had been having a close personal relationship with a senior work colleague who lived with the family but who was deeply resented by the patient. Her past history included investigation by her family doctor for frequency of urination which had revealed no abnormality. Full blood picture had been taken a few months previous to referral and a haemoglobin was noted as $12.3 \mathrm{~g} / \mathrm{dl}$ with a mean corpuscular volume (MCV) of $103 \mathrm{fl}$. Poor diet had

Correspondence: W.J. Andrews, M.D., M.R.C.P.

Accepted: 6 March, 1986 been suspected but no dietary history was available and no other blood tests had been taken.

On questioning the patient admitted to a slight weight loss only a 'few pounds' over 4 months and menstruation had been regular. Vomiting tended to occur in the evenings and the vomitus apparently consisted of food just previously eaten. Dietary history was difficult but the patient only admitted to the regular consumption of a half slice of bread accompanied by a cup of milky tea. 'Fried chipped potatoes' were often eaten while alone and on most evenings, a practice initially encouraged by her mother because of the paucity of her diet and her refusal of meat and vegetables over an indefinite period. She denied any abuse of diuretics or laxatives.

On examination she weighed $52.7 \mathrm{~kg}$ corresponding to a height of $165.1 \mathrm{~cm}$ (normal weight range $49-54 \mathrm{~kg}$, Metropolitan Life Insurance Tables 1959). Body Mass Index was $19.4 \mathrm{~kg} / \mathrm{m}^{2}$. She was clinically anaemic, mildly jaundiced but without other physical signs.

Laboratory investigations showed a haemoglobin of $6.6 \mathrm{~g} / \mathrm{dl}$ with $\mathrm{MCV} 106 \mathrm{fl}$, mean corpuscular haemoglobin (MCH) $36.6 \mathrm{pg}$ and mean corpuscular haemoglobin content (MCHC) $33.8 \mathrm{~g} / \mathrm{dl}$ with a white cell count (WCC) of $2.4 \times 10^{9} / 1$ and a platelet count of $177 \times 10^{9} / 1$. Differential WCC was within normal limits but there was marked hypersegmentation of the polymorphs. Red cell morphology was normal apart from the macrocytosis. Blood urea and electrolytes were normal apart from a low serum sodium $\left(\mathrm{Na}^{+}\right)$of $131 \mathrm{mmol} / \mathrm{l}$. Gravidex pregnancy test was negative and gastroscopy displayed only mild erythema of the lower oesophagus.

Serum folate was unrecordable but serum iron, total iron binding capacity, serum ferritin, serum $\mathbf{B}_{12}$ were all recorded as normal. Serum carotene was reduced at $0.37 \mu \mathrm{mol} / 1, \mathrm{D}-\mathrm{xylose}$ absorption was normal, jejunal biopsy showed a normal mucosa. Serum LDH was elevated at $6740 \mathrm{IU} / 1$, serum bilirubin was also raised 
to $570 \mathrm{~mol} / 1$, but other liver enzymes were normal. Serum haptoglobins were slightly reduced at $0.02 \mathrm{~g} / \mathrm{dl}$ and the reticulocyte count was $1 \%$. Serum cortisol was normal.

During the first day of admission she refused all food except a single slice of toast with crust left uneaten and three small cups of milky tea. After a visit by the mother in the evening she was noted to vomit and again on the third evening of admission she vomited profusely after irritating the back of her throat with her fingers.

Despite the girl's own image of herself as overweight, dietary encouragement by the hospital dietitian and all the ward staff was attempted in conjunction with daily oral folic acid $(15 \mathrm{mg})$, ferrous sulphate $(300 \mathrm{mg})$ and intramuscular vitamin $\mathbf{B}_{12}$ $(1000 \mu \mathrm{g})$. Within 5 days of beginning therapy the reticulocyte response was $28 \%$ and the haemoglobin had risen to $8.3 \mathrm{~g} / \mathrm{dl}$. Vomiting ceased and intensive social support was given and continued after discharge by the community nursing services.

At review, 3 weeks post-discharge, her weight had increased by $3.16 \mathrm{~kg}$ and her haemoglobin had risen to $12.7 \mathrm{~g} / \mathrm{dl}$ with normal haematological indices. No further vomiting had occurred although she still experienced a fear of fatness and she was still only consuming meat on infrequent occasions.

\section{Discussion}

Anaemia has not been noted to be a conspicuous presenting feature of anorexia or bulimia nervosa (Harris, 1983). Subclinical deficiencies of iron and folate have been recorded but morphological abnor-

\section{References}

DIAGNOSTIC AND STATISTICAL MANUAL OF MENTAL DISORDERS (1980). Third Edition. American Psychiatric Association: Washington, DC.

HARRIS, R.T. (1983). Bulimarexia and related serious disorders with medical complications. Annals of Internal Medicine, 99, 800.

HERTZOG, D.B. \& COPELAND, P.M. (1985). Eating disorders. New England Journal of Medicine, 313, 295.

LACEY, J.H. (1983). Bulimia nervosa, binge eating, and malities of white or red blood cells have been striking by their absence, with 'spur' cells regarded as the most characteristic abnormality seen in patients with anorexia nervosa (Mant \& Farragher, 1972).

Our patient fulfills the recognized diagnostic criteria for bulimia nervosa of Russell (1979) and of the American Psychiatric Association's Diagnostic and Statistical Manual of Mental Disorders (D.S.M. 111, 1980).

It is surprising that folate deficiency which theoretically is highly probable has not previously been noted to be a feature of bulimia nervosa. Perhaps these patients generally consume sufficient folate containing food to obviate severe folate deficiency but our patient seems to have consumed largely carbohydrate and fat, both for an unknown period before, and during, the bulimia phase. This patient was aware of her abnormal diet but the pre-bulimic paucity of diet is probably attributable to poor dietary education and her unstable social background.

Short term haematinic replacement therapy has so far been successful but the patient's diet since discharge from hospital appears not to have markedly improved, which may be a worrying feature since some (Russell, 1979; Harris, 1983) hold that the long term prognosis may be less favourable than anorexia nervosa, although this has been disputed by Lacey (1983).

\section{Acknowledgements}

The authors would like to thank Miss J. Straghan for typing this manuscript.

psychogenic vomiting: a controlled treatment study and long term outcome. British Medical Journal, 286, 1609.

MANT, M.S. \& FARRAGHER, B.S. (1972). The haematology of anorexia nervosa. British Journal of Haematology, 23, 737.

RUSSELL, G.F.M. (1979). Bulimia nervosa: an ominous variant of anorexia nervosa. Psychological Medicine, 9, 429. 